\title{
EXPLORASI PEMBELAJARAN OPERASI PECAHAN SISWA SEKOLAH DASAR MENURUT TEORI GRAVEMEIJER DI KABUPATEN NGADA NTT
}

\section{EXPLORATION FRACTION OPERATION LEARNING OF ELEMENTARY SCHOOLS STUDENTS ACCORDING TO GRAVEMEIJER THEORY IN NGADA REGENCY, NTT}

\author{
Gregorius Sebo Bito, Sugiman \\ FKIP Universitas Flores, Universitas Negeri Yogyakarta \\ eris391@yahoo.co.id, sugiman_uny@yahoo.com
}

\begin{abstract}
Abstrak
Tujuan penelitian ini adalah untuk mengetahui perkembangan belajar operasi pecahan siswa sekolah dasar menurut teori Gravemeijer di Kabupaten Ngada NTT. Jenis penelitian kualitatif fenomenologi digunakan untuk mencapai tujuan penelitian. Dalam penelitian ini Hypothetical Learning Trajectory (HLT) memainkan peranan penting sebagai instrumen penelitian. Perangkat pembelajaran yang disusun untuk menjalankan serangkaian aktivitas belajar dalam HLT telah dikonsultasikan dengan dua orang ahli Pembelajaran Matematika selanjutnya diuji coba pada kelompok kecil yaitu lima siswa Kelas IV Sekolah Dasar Katolik Bomari Langa pada tahap eksperimen pilot. Selanjutnya HLT dibandingkan dalam proses pembelajaran sebenarnya pada tahap eksperimen pengajaran dengan 24 siswa. Berdasarkan analisis ditemukan bahwa siswa dapat berkembang dalam belajar operasi pecahan dengan menggunakan tingkat aktivitas yang berbeda berdasarkan pendekatan PMR menurut teori Gravemeijer. Pada level pertama yaitu level situasional, Drama Matematika dapat menstimulasi pengetahuan informal siswa tentang prosedur operasi penjumlahan dan pengurangan pecahan. Pada level referensial, untaian manik-manik dan kartu pecahan menjadi model dari situasi drama matematika yang merupakan jembatan menuju gagasan penggunaan garis bilangan untuk operasi penjumlahan dan pengurangan pecahan. Pada level ketiga yaitu level general, siswa dapat menggunakan garis bilangan sebagai model untuk operasi penjumlahan dan pengurangan pecahan. Pada level formal, dengan bantuan untaian bilangan membawa siswa mengkonstruksi soal cerita sendiri dan menyelesaikan soal cerita yang dihasilkan dengan prosedur formal operasi penjumlahan dan pengurangan pecahan.
\end{abstract}

Kata Kunci: Teori Gravemeijer, hipotesis trayektori belajar, penjumlahan dan pengurangan pecahan.

\begin{abstract}
This study aims to determine the students progress of learning operations on fractions according to Gravemeijer theory in Ngada Regency, East Nusa Tenggara. A qualitative fenomenology research design was selected to attain the research objective. In this research, a hypothetical learning trajectory (HLT) played an important role as a research instrument. The learning kits constructed to implement a series of learning activities in HLT were consulted with two experts in mathematics learning and were tried out to a small group consisting of five Grade IV students of Sekolah Dasar Katolik Bomari Langa in the pilot experimental stage. Then, HLT was compared with the actual learning process in the experimental stage involving 24 students. Based on the analysis, it is found out that the students can develop more in the learning of concepts of fraction operations through activity levels different from those based on the RME according Gravemeijer theory. At the first level, namely the situational level, a mathematics drama can stimulate the students' informal knowledge of the procedure of addition and subtraction operations on fractions. At the referential level, a string of beads and fraction cards become a model for the mathematics drama situation serving as a bridge to the idea of using a number line for the addition and subtraction operations on fractions. At the third level, namely the general level, the students can use a number line as a model for the addition and subtraction operations on fractions. At the formal level, with the aid of a series of numbers, the students construct their own word problems and solve them by means of the formal procedure of the addition and subtraction operations on fractions.
\end{abstract}

Keywords: Gravemeijer Theory, hypothetical learning trajectory, addition and subtraction fractions 


\section{Pendahuluan}

Pecahan telah terbukti sebagai materi yang kompleks dan sulit untuk dipahami oleh anak-anak (Van Niekrek, et al, 1999, p.1). Selain itu, makna pecahan yang bervariasi merupakan salah satu dari penyebab kesulitan anak dalam pembelajaran pecahan (Permatasari, Junianti \& Patahudin, 2012, p.17). Di sisi lain, pecahan sangat berguna bagi siswa karena materi ini akan membantu mereka untuk mempelajari materi matematika yang lain di jenjang berikutnya. Kurangnya pemahaman siswa tentang pecahan merupakan faktor yang berkontribusi pada penguasaan matematika yang tidak memadai (Mullis, et al, 1997, p.28). Post, Behr \& Lesh (Wheeldon, 2008, p.28) menemukan bahwa siswa tidak dapat membedakan antara operasi bilangan cacah dan operasi bilangan pecahan. Hal ini karena sebelumnya pada mereka telah terbentuk pengetahuan yang mapan tentang bilangan asli (Liu, Xin \& Li, 2012, p.47). Di Indonesia hasil penelitian Soedjadi (Nalole, 2008, p.138) menyatakan bahwa salah satu masalah yang paling menonjol di pendidikan dasar adalah pada materi pecahan.

Selain temuan yang telah dipaparkan di atas, para peneliti telah mengidentifikasi beberapa masalah utama dalam proses pembelajaran matematika. Pembelajaran cenderung ditujukan hanya untuk mencapai pemahaman instrumental, dimana siswa dapat menggunakan rumus untuk menyelesaikan suatu soal tetapi tidak memahami bagaimana rumus itu diperoleh dan mengapa rumus itu dapat berfungsi demikian (Marpaung dalam Sumaji, 2008, p.261). Pembelajaran demikian masih dipraktikan oleh hampir seluruh guru di Ngada, dimana guru sangat mengandalkan materi pada buku pelajaran yang beredar di pasaran, padahal menurut Zulkardi (2002, p.6), buku pelajaran di Indonesia lebih banyak memuat serangkaian aturan, algoritma dan tidak memiliki aplikasi yang berdasarkan pengalaman kongkrit siswa.

Kondisi seperti ini tentunya bertentangan dengan tujuan pembelajaran yaitu membawa siswa pada pemahaman. Tanpa pemahaman, pembelajaran matematika direduksi menjadi menghafal rumus dan aturan aturan matematika sehingga belajar menjadi tidak bermakna, apalagi berguna (Boulet, 1998, p.18). Pembelajaran yang membawa siswa belajar konsep matematika secara bermakna merupakan penekanan penting dalam Pendidikan Matematika Realistik (PMR) yang belakangan ini sudah dipraktikan di beberapa daerah di Indonesia. Teori PMR merupakan salah satu teori yang terus menerus dikembangkan dan disempurnakan dalam siklus berkelanjutan dari merancang, melakukan eksperimen, analisis dan refleksi. Melalui desain riset dengan konteks "membagi serenteng makanan ringan" serta konteks "menaikan dan menurunkan penumpang" akan diinvestigasi perkembangan siswa dalam belajar operasi penjumlahan dan pengurangan pecahan secara bertahap berdasarkan level aktivitas pemodelan dalam PMR.

Gravemeijer (1994, p.90) mengemukakan bahwa ada tiga prinsip utama dalam PMR, yaitu: (a) guided reinvention/progressive mathematizing, (b) didactical phenomenology dan (c) self-developed models. Gravemeijer (1994, p.101) menguraikan perbedaan model of dan model for dalam empat tingkatan aktivitas yaitu: situasional, referensial, general dan formal. Level situasional merupakan yang paling dasar dari pemodelan dimana pengetahuan dan model masih berkembang dalam konteks situasi masalah yang digunakan. Pada level referensional, strategi dan model yang dikembangkan tidak berada dalam konteks situasi, melainkan sudah merujuk pada konteks dimana siswa membuat model untuk menggambarkan situasi konteks sehingga hasil pemodelan pada model ini disebut model dari (model of) situasi. Model yang dikembangkan siswa pada level general sudah mengarah pada pencarian solusi secara matematis yang disebut model untuk (model for) penyelesaian masalah. Pada level formal yang merupakan tahapan perumusan dan penegasan konsep matematika yang dibangun siswa, siswa sudah bekerja dengan menggunakan simbol dan representasi matematis.

Tujuan penelitian ini adalah untuk mengetahui perkembangan siswa belajar operasi penjumlahan dan pengurangan pecahan kelas IV Sekolah Dasar dengan level aktivitas pemodelan menurut teori Gravemeijer.

\section{Metode}

Penelitian ini menggunakan pendekatan kualitatif dan jenis penelitian fenomenologi. Untuk memudahkan dalam memperoleh data penelitian, peneliti dibimbing oleh sebuah instrumen yang dinamakan Hypothetical Learning Trajectory (HLT). HLT terdiri dari aktivitas belajar, deskripsi aktivitas, material yang mendukung proses pembelajaran dan konjektur atau dugaan pemikiran siswa yang mungkin akan berkembang dalam proses pembelajaran. 
HLT yang telah disusun pada tahap awal diuji coba dalam tahap eksperimen pilot dengan siswa sebanyak lima orang. Selanjutnya dalam melakukan eksperimen di kelas, kegiatan pembelajaran dinilai, direvisi, dan dirancang setiap hari selama eksperimen pengajaran. Wawasan dan pengalaman yang diperoleh dalam eksperimen pilot ini menjadi pertimbangan untuk modifikasi HLT yang akan digunakan dalam pembelajaran kelas dengan siswa sebanyak 25 Orang. Dalam tahap analisis data, semua data selama eksperimen pengajaran dianalisis dengan cara membandingkan HLT dengan pembelajaran yang sebenarnya. Berdasarkan analisis tersebut maka HLT direvisi berdasarkan dugaan baru tentang berbagai gagasan atau pemikiran siswa dalam pembelajaran.

Dalam analisis data, peneliti melakukan kegiatan utama yaitu membandingkan HLT dengan pembelajaran yang sebenarnya untuk menyelidiki dan menjelaskan bagaimana siswa memperoleh pemahaman mereka tentang operasi penjumlahan dan pengurangan pecahan. Keluaran dari analisis data ini adalah untuk untuk tujuan: (1) menggambarkan proses belajar siswa yang terdiri dari cara siswa dalam berpikir dan memecahkan masalah serta alasan siswa menggunakan strategi tertentu, argumen siswa ketika menjelaskan gagasannya saat presentasi maupun dalam pekerjaan siswa; (2) menggambarkan situasi di mana siswa membutuhkan bantuan dalam memahami dan memecahkan masalah dan sifat bantuan yang terbukti bermanfaat (3) membandingkan strategi, penjelasan, dan pertanyaan siswa tentang masalah tertentu selama kegiatan pembelajaran; (4) Membuat kesimpulan berdasarkan data. Kesimpulan ini berfokus pada menjawab pertanyaan penelitian, memberikan rekomendasi untuk perbaikan HLT berikutnya, untuk praktek pendidikan matematika di Indonesia dan untuk penelitian lebih lanjut.

\section{Hasil Penelitian}

Hasil eksperimen pembelajaran yang dilakukan yang merupakan implementasi dari keempat tipe aktivitas matematika berdasarkan tahap pengembangan model dalam PMR menurut teori Gravemeijer adalah sebagai berikut.

\section{Level Situasional}

Pada level situasional, siswa akan melakukan Drama Matematika dengan memperagakan Skenario 1 dan Skenario 2. Tujuan dari aktivitas ini adalah untuk mengorientasikan siswa pada pada masalah kontekstual yang sering mereka alami setiap hari dalam hubungannya dengan masalah matematika yang akan dipelajari.

\section{Skenario 1}

Pada suatu siang sepulangnya dari pasar Bajawa, ibu membawa oleh oleh berupa 1 renteng makanan ringan untuk Owyn. Siang itu Owyn langsung makan 1/5 bagian dan pada sore harinya ia menghabiskan lagi 2/5 bagian. Sisanya akan diberikan pada temannya.

Dari pengamatan terlihat siswa tidak kesulitan dalam memperagakan Skenario 1. Siswa dapat menentukan makanan ringan yang dimakan Owyn pada siang hari sebanyak 1/5 bagian (2 bungkus) dan sore harinya $2 / 5$ bagian (4 bungkus) sehingga total yang dimakan Owyn adalah sebanyak $3 / 5$ bagian (6 bungkus). Selanjutnya, siswa menentukan sisa dari makanan ringan yaitu $2 / 5$ bagian (4 bungkus) Untuk mengetahui gagasan siswa berkaitan dengan aktivitas peragaan Skenario 1, peneliti melakukan percakapan dengan Telin yang berperan membagi makanan ringan sebagai berikut.

Peneliti: Ok, Telin. Bagaimana kamu tahu bahwa yang akan diberikan Owyn pada temannya adalah 4 bungkus.

Telin: Dari soal pak. Siang dia makan 1/5 bagian.

Peneliti: Berarti 1/5 bagian itu sama dengan 2 bungkus?

Telin: Iya pak. Kalau 1/5 itu berarti makanan ringan tadi dibagi 5 bagian.

Peneliti: Masing-masing bagian besarnya?

Telin: 1/5 Pak. Jadi siang dia makan 1 bagian atau 1/5, sore dia 2 bagian atau 2/5, jadi dia sudah makan sebesar 3/5 bagian.

Peneliti: Itu artinya yang kamu berikan pada Rufina berapa besarnya?

Telin: Itu yang saya berikan ke Rufina untuk temannya Owyn besarnya 2/5.

Berdasarkan percakapan ini siswa dapat diketahui bahwa siswa memahami apa yang mereka hasilkan dalam Skenario 1. Hal ini dapat terjadi karena tools yang digunakan adalah serenteng makanan ringan yang diketahui isinya 10 bungkus. Setelah melakukan peragaan Skenario 1 siswa mengerjakan soal No. 1 pada LKS yang menggambarkan Drama Matematika yang telah mereka lakukan. Pada soal 1 (a) siswa menggambarkan aktivitas pembagian makanan ringan yang telah mereka lakukan, selanjutnya pada soal 1(b) siswa dapat menentukan makan- 
an ringan yang diberikan Owyn pada temannya sebesar 2/5 bagian, dan pada soal 1(c) siswa dapat menentukan makanan ringan yang dimakan Owyn sebesar 3/5 bagian. Pengetahuan siswa tentang pembagian bilangan cacah dan pengertian pecahan sebagai part-whole relation dari aktivitas mempartisi serta interpretasi makanan ringan yang dimakan (misalnya: makan lagi, ambil lagi) dan sisa makanan ringan pada aktivitas Drama Matematika menuntun siswa untuk sukses menyelesaikan soal No.1 (Gambar $1)$.

\section{Skenario 2.}

Bemo Sempati berangkat dari Langa menuju Terminal Bajawa dengan 1/3 dari jumlah tempat duduknya terisi penumpang. Di Watujaji bemo berhenti dan menaikkan penumpang sehingga $1 / 4$ bagian dari jumlah tempat duduk lagi terisi penumpang.

Dalam aktivitas menaikan dan menurunkan penumpang, siswa mengalami kesulitan karena siswa tidak mengetahui kapasitas penumpang (jumlah tempat duduk pada Bemo). Peran guru untuk memprovokasi siswa sangat penting terutama membangkitkan pengetahuan yang telah ada pada siswa seperti pada percakapan berikut.

Peneliti: Rizal, tadi kamu tidak dapat menaikkan penumpang sebanyak 1/3 bagian yang dari Langa, 1/4 bagian yang naik di Watujaji dan 1/6 yang turun di Waewoki.Kenapa Rizal?Sulit ya?
Rizal: Iya, pak. Saya tidak tau jumlah penumpangnya berapa.

Peneliti: Bagaimanakah caranya agar kalian dapat menentukan 1/3, 1/4 dan 1/6 bagian dari jumlah total tempat duduk. Ok. Berapa jumlah kursi sehingga kita bisa bagi 3 bagian sama banyak, bagi 4 bagian sama banyak dan bagi 6 bagian sama banyak?

Rizal: Oh iya pak, Berarti 1/3 bagian tempat duduk yang diisi penumpang yang dari Langa ada 4 tempat duduk.

Peneliti:Bagaimana kamu bisa menentukan itu? Rizal: Karena 12: 3=4, 12:4=3, 12/6=2

Peneliti: Ok, berarti tempat duduk yang diisi penumpang dari langa ada berapa?

Rizal: 4 kursi dari 12 kursi Pak atau bisa ditulis $4 / 12$.

Peneliti: Artinya apa tuh Rizal?

Rizal: 1/3 diganti dengan 4/12.

Karena siswa memahami 1/3, 1/4, 1/6 sebagai besar setiap unit dari hasil partisi pada pembelajaran di Kelas III dan $\operatorname{KPK}(3,4,6)$ maka setelah pertanyaan provokasi tersebut, siswa menentukan bahwa jumlah tempat duduk atau kapasitas penumpang adalah 12. Setelah mengetahui kapasitas penumpang Bemo siswa tidak terlihat kesulitan menaikan dan menurunkan penumpang berdasarkan Skenario 2 (Gambar 2).

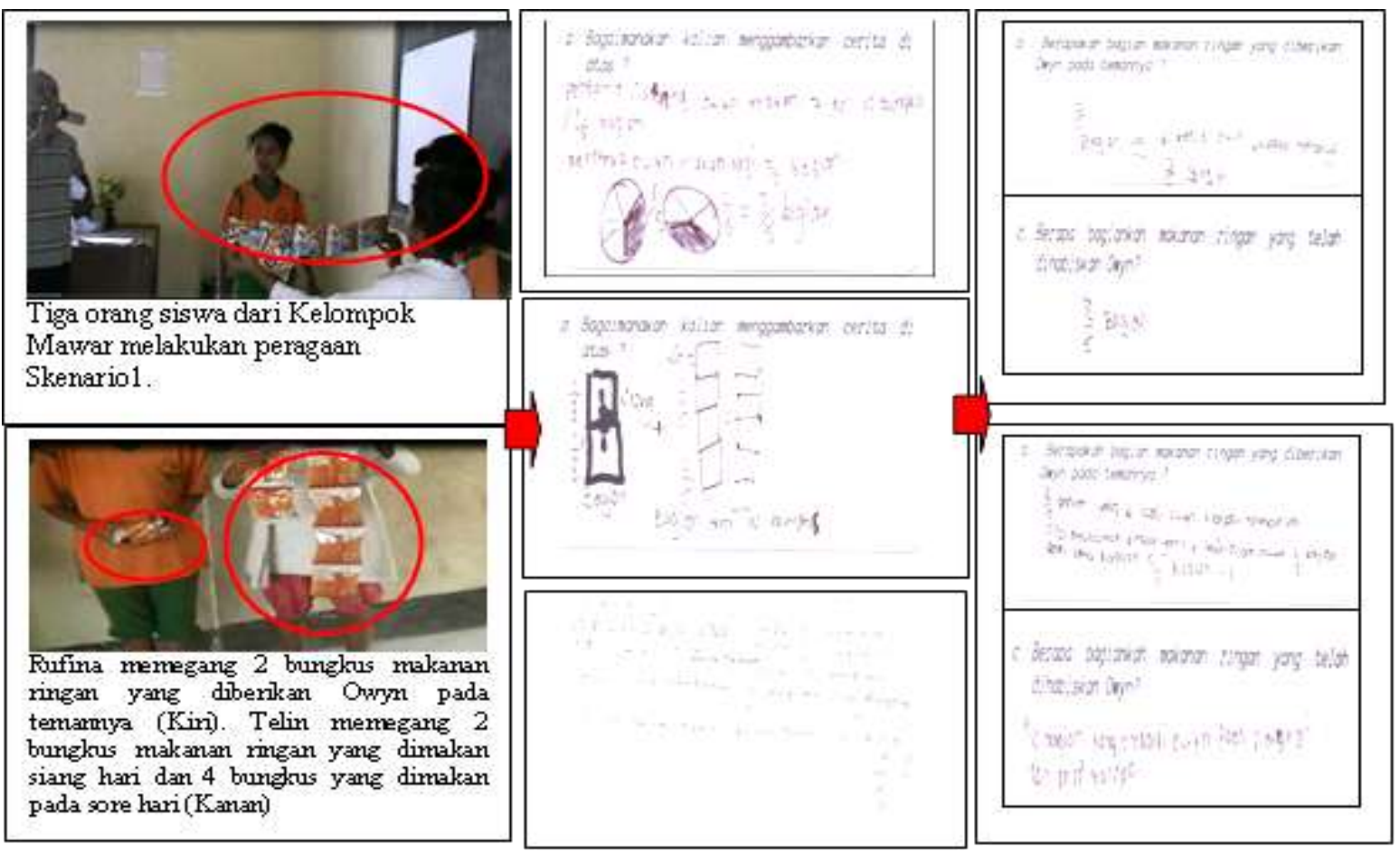

Gambar 1.Aktivitas Drama Matematika (Skenario 1) 


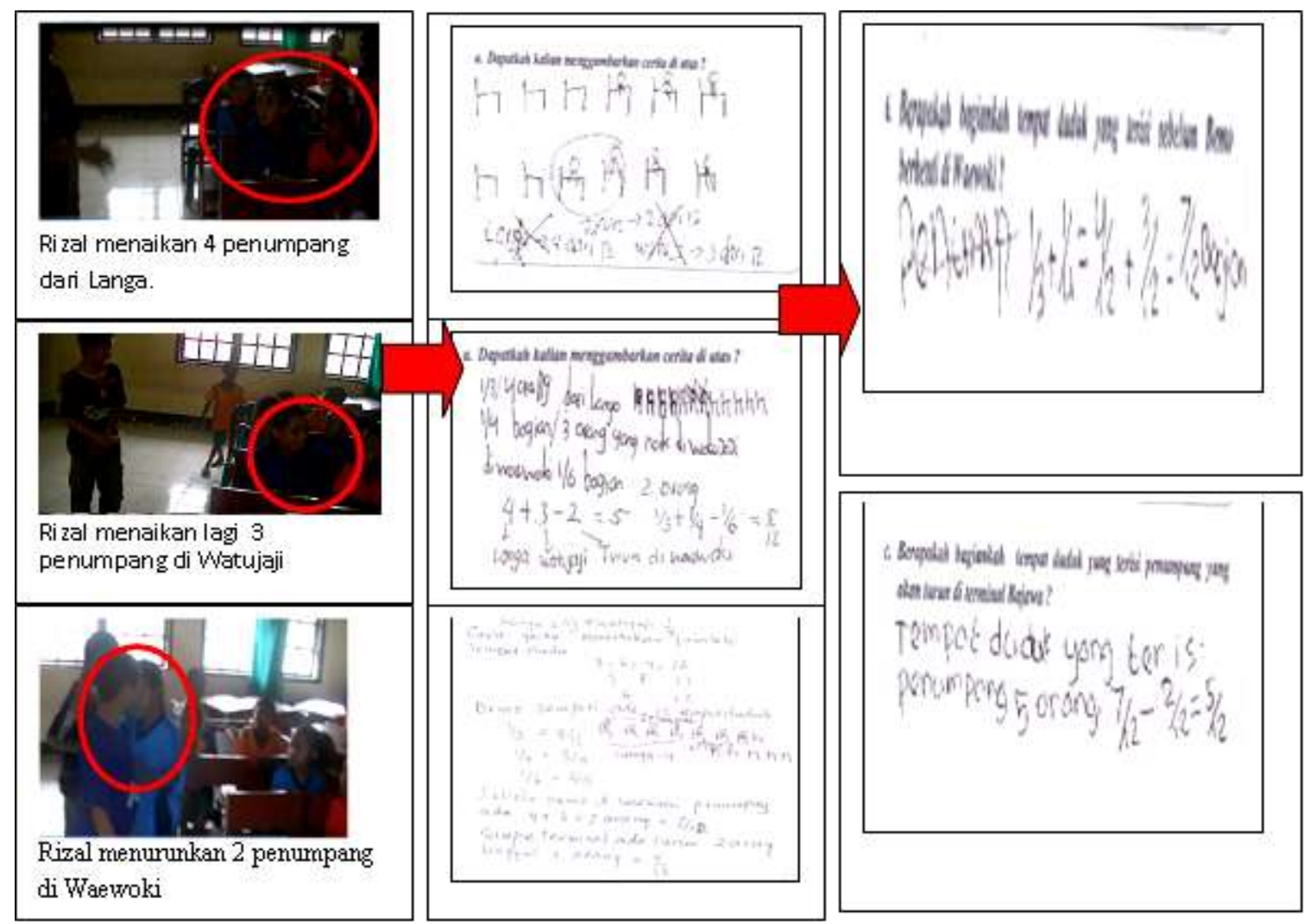

Gambar 2.Aktivitas menaikkan dan menurunkan penumpang (Skenario 2)

Setelah melakukan drama dengan Skenario 2, siswa akan menggambarkan aktivitas tersebut dengan menyelesaikan soal No. 2 pada LKS. Interpretasi aktivitas menaikan serta menurunkan penumpang (misalnya naik, turun) merupakan bagian penting dalam aktivitas ini. Siswa menggambarkan situasi dengan kursikursi dan bulatan kecil sebagai penumpang dan memberi tanda pada bulatan sebagai gambaran penumpang yang turun. Selanjutnya, siswa dapat menentukan penumpang yang naik dari langa $1 / 3$ bagian tempat duduk dan naik lagi di Watujaji $1 / 4$ bagian (sebelum Bemo berhenti di Waewoki untuk menurunkan penumpang) yaitu sebanyak 7/12 bagian dari tempat duduk.

Hal ini menunjukkan siswa dapat melakukan operasi penjumlahan pecahan dengan penyebut tidak sama dari situasi menaikan (tambah) dan menurunkan (kurang) penumpang. Dari percakapan dengan siswa pada Drama Matematika dan hasil pekerjaan siswa pada soal 1 dan 2 dapat dilihat bahwa siswa dapat menemukan penyelesaian masalah kontekstual dengan menggunakan aktivitas yang menggambarkan kehidupan kesehariannya. Selain itu dalam menyelesaikan penjumlahan dan pengurangan pecahan dengan penyebut yang tidak sama, siswa menyadari bahwa mengganti pecahan dengan pecahan lain yang setara dapat membantu mereka menyelesaikan masalah.

Pada level ini pengetahuan prasyarat siswa sangat diperlukan yaitu pengetahuan tentang pengertian pecahan sebagai hubungan antara bagian-bagian dan sesuatu yang utuh (fraction as part of a whole/part-whole relation), kemampuan mempartisi sekumpulan objek diskrit (memproduksi pecahan) dan kemampuan menemukan kesamaan pecahan (generating equivalencies). Berawal dari mengalami situasi (masalah kontekstual) dalam aktivitas drama matematika), siswa dapat memodelkannya sendiri dengan menyusun, melambangkan dan memvisualisasikan drama tersebut. Hal ini sesuai dengan prinsip pertama dari PMR yaitu penggunaan masalah kontekstual (use of contextual problems) dimana aktivitas membagi makanan ringan serta drama menaikkan dan menurunkan penumpang merupakan sumber untuk memproduksi sendiri prosedur operasi penjumlahan dan pengurangan pecahan. Dengan demikian kedua konteks yang digunakan dalam aktivitas Drama Matematika sukses menstimulasi penalaran siswa tentang penjumlahan dan pengurangan pecahan. 
Level Referensial

Pada level ini siswa secara berkelompok akan memperagakan Skenario 1 dan Skenario 2 menggunakan manik-manik dan kartu pecahan kosong. Manik-manik putih menggambarkan makanan ringan yang sudah dimakan dan kursi angkot yang kosong. Manik-manik hitam menggambarkan makanan ringan yang belum dimakan dan kursi angkot yang diduduki penumpang. Sedangkan kartu pecahan bertujuan untuk mempartisi manik-manik ke beberapa bagian yang sama sesuai skenario. Setelah siswa memodelkan Skenario 1 dan Skenario dengan manik-manik dan kartu pecahan, siswa menggambarkan untaian manik-manik yang telah digantungkan kartu pecahan yang dihasilkannya pada LKK II (Gambar 3 \& Gambar 4).
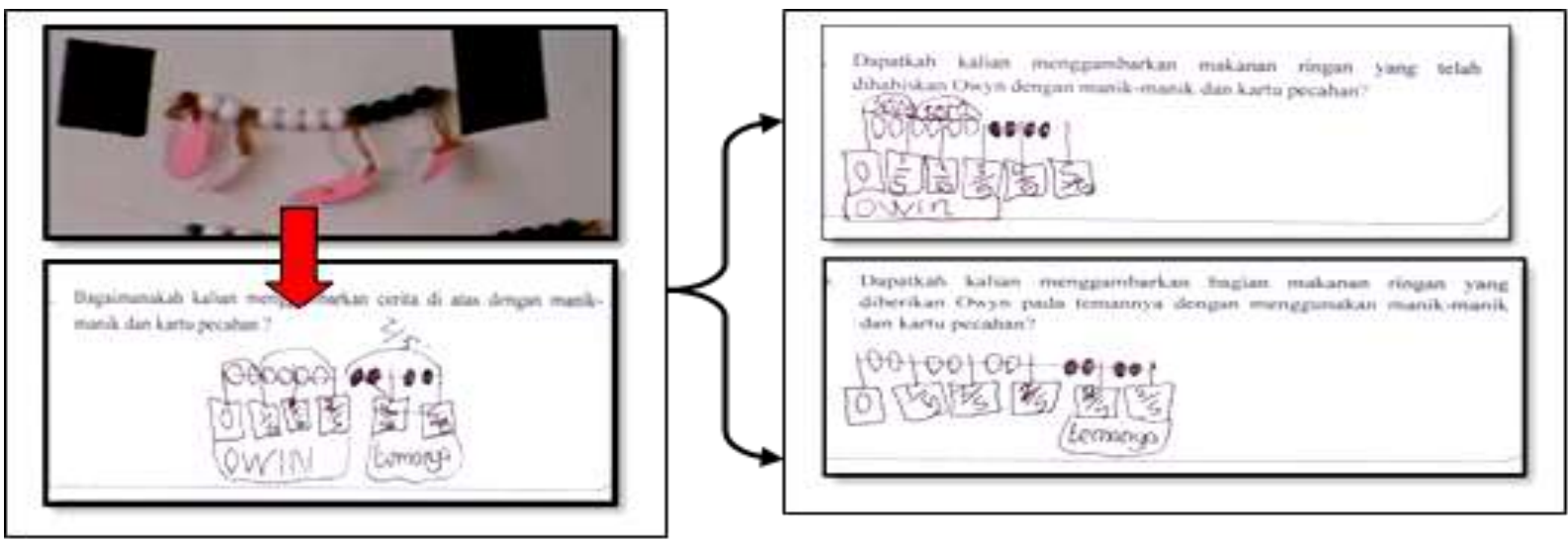

Gambar 3.Siswa Menerjemahkan Skenario 1 dalam Untaian Manik-manik dan Kartu Pecahan dan Menggambarkannya dalam Lembar Kerja Kelompok.
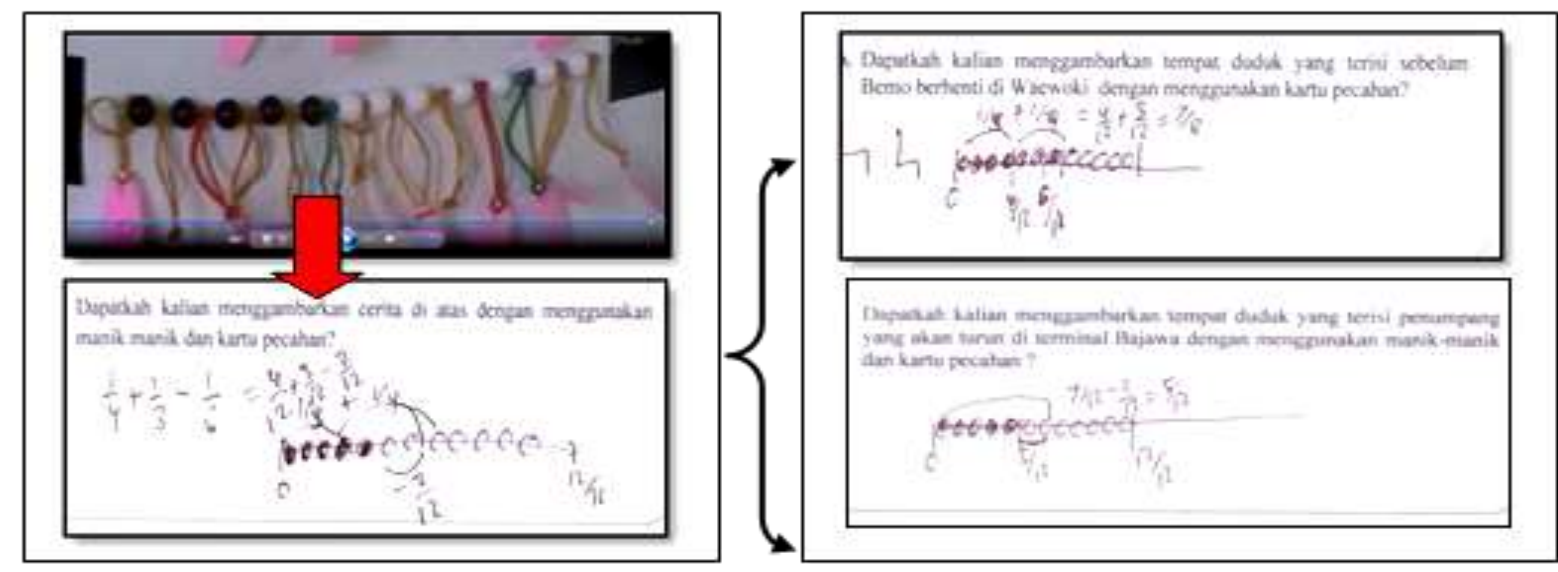

Gambar 4.Siswa Menerjemahkan Skenario 1 dalam Untaian Manik-manik dan Kartu Pecahan dan Menggambarkannya dalam Lembar Kerja Kelompok.

Pada level aktivitas kedua, siswa, menggunakan manik-manik (hitam dan putih), kartu pecahan kosong, dan senar. Pada tahap ini siswa memodelkan situasi dalam seuntai manikmanik yang digantungkan kartu pecahan. Selanjutnya siswa menggambarkanya sesuai untaian manik-manik yang dihasilkan. Hal ini sesuai dengan prinsip kedua dari PMR yaitu, penggunaan model-model (use of models) dimana untaian manik-manik dapat menjadi jembatan menuju pada operasi penjumlahan dan pengurangan menggunakan garis bilangan.

\section{Level General}

Sebagai refleksi dari aktivitas sebelumnya, saat ini guru memimpin diskusi kelas. Kongres Matematika dilaksanakan untuk memfasilitasi dan membangun pemahaman siswa untuk menggunakan garis bilangan yang dapat membantu membawa mereka pada gagasan tentang prosedur operasi penjumlahan dan pengurangan pecahan. Manfaat yang diperoleh dalam Kongres Matematika tersebut adalah tidak hanya bertujuan untuk mengkomunikasikan gagasan siswa tetapi juga dapat memberi stimulus 
pada siswa yang lain untuk mengembangkan strategi yang berbeda. Hal ini berhubungan dengan prinsip keempat dari PMR yaitu interaktivitas dimana siswa dapat membagi apa yang dipikirkan mereka dalam diskusi kelas. Dalam kesempatan tersebut guru memegang peranan penting untuk mengatur jalannya proses diskusi. Garis bilangan merupakan model yang sangat berguna untuk membimbing siswa menuju prosedur formal operasi penjumlahan dan pengurangan pecahan. Pada aktivitas ini garis bilangan kosong digunakan untuk pemodelan yang lebih spesifik dengan memanfaatkan kontribusi siswa sebelumnya yaitu peragaan dan gambaran masalah menggunakan untaian manik-manik.

Berdasarkan prinsip ketiga dari PMR yaitu, penggunaan kreativitas dan kontribusi siswa, gambaran dari untaian manik-manik sebagai model dari situasi ditransformasikan pada garis bilangan kosong sebagai model untuk penalaran matematika yang lebih formal (Gambar 5). Transformasi ini merupakan momen belajar yang penting bagi siswa dimana mereka dapat menggunakan model untuk beranjak dari konteks yang konkrit menuju matematika yang lebih formal.
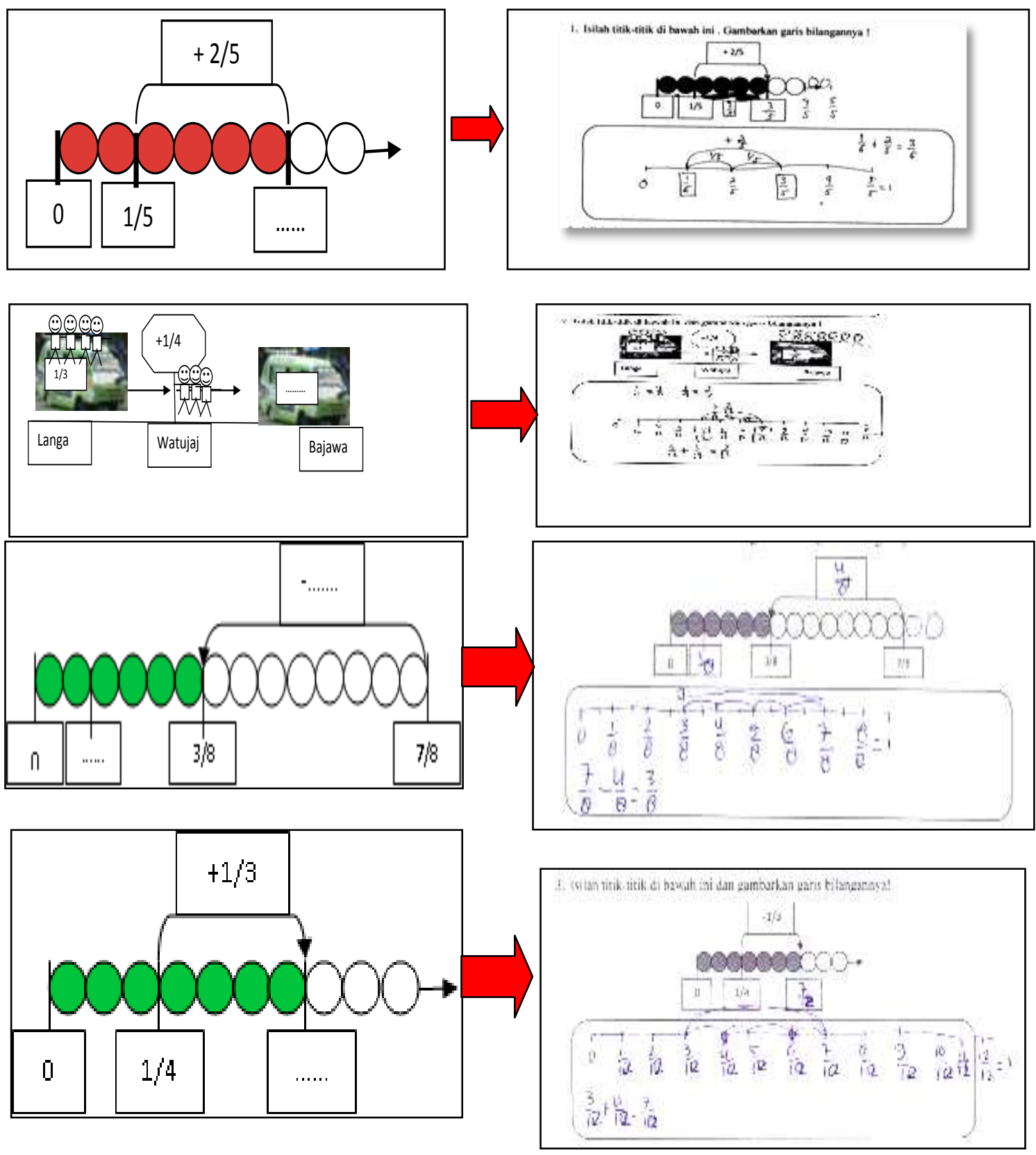

Gambar 5.Siswa Melengkapi Garis Bilangan Kosong dan Menggambarkan Garis Bilangan Pecahan. 
Level Formal

Aktivitas penalaran matematika formal yang tidak lagi tergantung pada dukungan model untuk kegiatan matematika. Fokus dari diskusi menuju karakteristik model yang lebih spesifik yang terkait dengan penjumlahan dan pengurangan pecahan. Dalam aktivitas ini siswa sudah bekerja dengan simbol-simbol pecahan yang lebih formal yaitu untaian bilangan pecah- an (misalnya: $\frac{1}{3}+\frac{1}{4}, \frac{3}{5}+\frac{1}{10}, \frac{3}{7}+\frac{1}{7}$ dan $\frac{3}{5}-\frac{1}{10}$ ) dengan menggunakan aturan yang telah ditemukan sendiri pada aktivitas sebelumnya. Siswa akan membuat soal sendiri dengan dipandu untaian bilangan sebagai model formal. Setelah membuat soal sendiri siswa akan menyelesaikannya dalam bahasa matematika formal (Gambar 6).

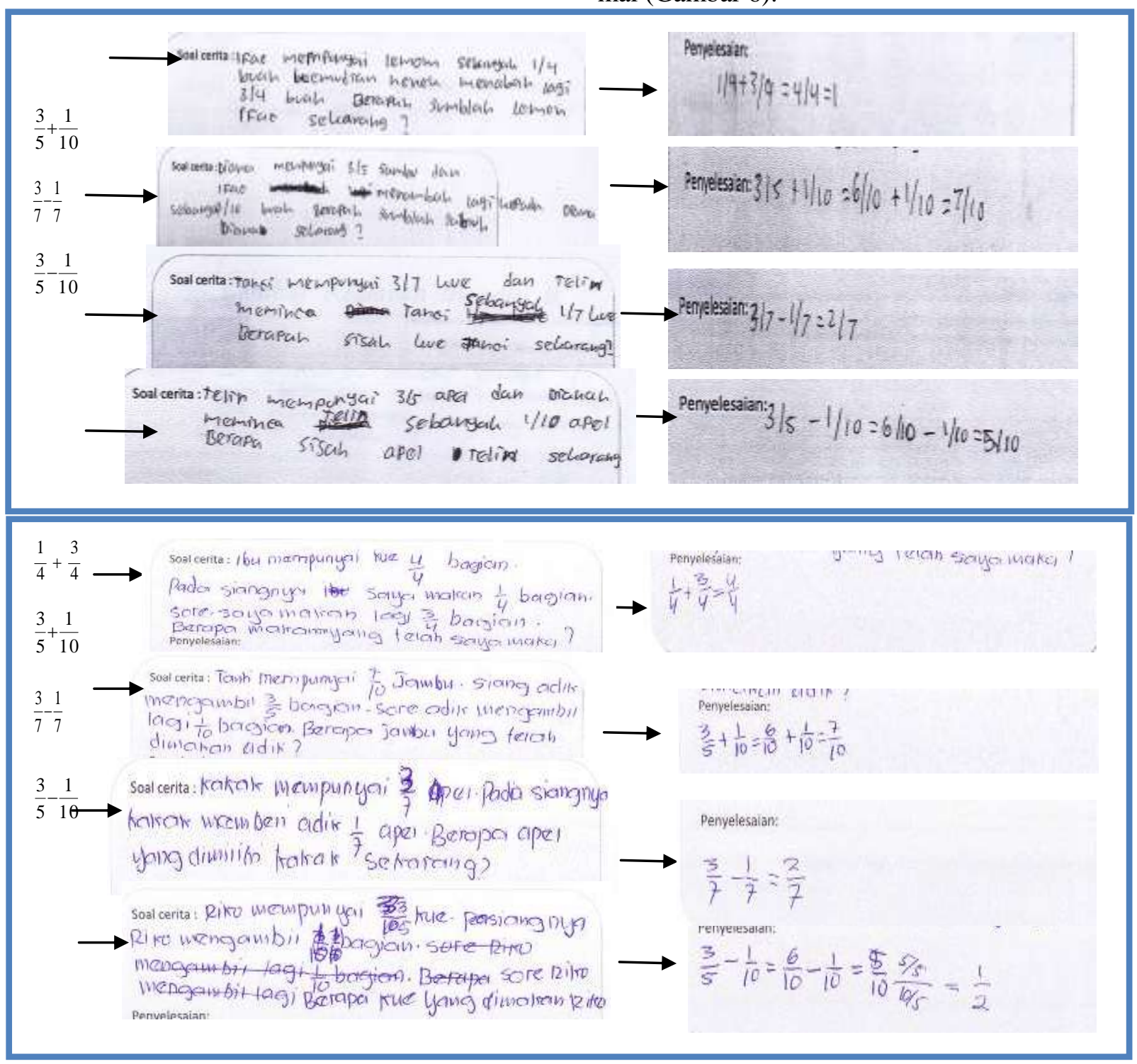

Gambar 6. Siswa Membuat Soal Cerita Sendiri dan Menyelesaikannya

Berdasarkan analisis data dapat dilihat bahwa semua dugaan peneliti telah disusun dalam instrumen penelitian (HLT) terobservasi dalam proses pembelajaran. Selanjutnya segala aktivitas yang disusun dalam HLT berdasarkan tingkat aktivitas dalam pendekatan PMR dapat dilaksanakan sesuai yang diharapkan. Dan dari hasil tes akhir dapat dilihat bahwa siswa memi- liki peningkatan dalam belajar pecahan dengan tingkat aktivitas berbeda dan pembelajaran yang dilakukan sudah sesuai dengan karakteristik PMR menurut Gravemeijer. Implementasi dari keempat tipe aktivitas matematika dalam pembelajaran penjumlahan dan pengurangan pecahan dalam konteks membagi makanan ringan dan konteks menaikkan serta menurunkan 
penumpang yang merupakan jawaban atas pertanyaan penelitian adalah adalah sebagai berikut.

Pada aktivitas situasional, interpretasi penjumlahan dan pengurangan pecahan tergantung pada pemahaman dan interpretasi pada konteks yang diberikan. Aktivitas situasional pada penelitian ini adalah masalah membagi serenteng makanan ringan serta konteks menaikkan dan menurunkan penumpang. Interpretasi makanan ringan yang dimakan (makan lagi, ambil lagi) dan aktivitas menaikkan serta menurunkan penumpang (naik, turun) merupakan bagian penting dalam aktivitas ini.

Aktivitas referensial, yaitu model of mengacu pada kegiatan dengan aturan yang dijelaskan. Kegiatan siswa dianggap referensial ketika mereka awalnya menggunakan manikmanik hitam yang merepresentasikan makanan yang belum dimakan dan kursi yang masih terisi serta manik-manik putih merepresentasikan makanan ringan yang sudah dimakan dan kursi yang telah kosong. Pada aktivitas referensial ini representasi garis bilangan dari penyusunan kartu pecahan (potongan-potongan kertas yang telah ditulisi nama pecahan) yang digantungkan pada untaian manik-manik dapat digunakan untuk peragaan penjumlahan dan pengurangan pecahan.

Aktivitas general, yaitu model for untuk merujuk pada kerangka hubungan matematika. Model untuk penalaran matematika yang yang digunakan pada aktivitas ini adalah gambar garis bilangan. Dalam kegiatan ini, representasi garis bilangan pecahan diperkenalkan sebagai alat generalisasi untaian manik-manik yang digantungkan kartu pecahan pada aktivitas sebelumnya. Siswa diminta untuk menggambarkan hubungan antara pecahan-pecahan yang diperoleh dari pecahan yang dihasilkan. Selain itu, dalam kegiatan ini representasi garis bilangan dapat digunakan untuk membantu menjumlahkan pecahan dengan penyebut yang berbeda sebelum menggunakan konsep KPK yang telah dikenal sebelum pembelajaran materi pecahan.

Aktivitas penalaran matematika formal yang tidak lagi tergantung pada dukungan model untuk kegiatan matematika. Fokus dari diskusi menuju karakteristik model yang lebih spesifik yang terkait dengan penjumlahan dan pengurangan pecahan. Dalam aktivitas ini siswa sudah bekerja dengan simbol-simbol pecahan yang lebih formal dengan menggunakan aturan yang telah ditemukan sendiri pada akti- vitas sebelumnya. Siswa akan membuat soal sendiri dengan dipandu untaian bilangan (representasi dari penjumlahan dan pengurangan pecahan). Setelah membuat soal sendiri siswa akan menyelesaikannya dalam bahasa matematika formal.

Dengan demikian aktivitas-aktivitas yang telah disusun dalam HLT dapat mendukung siswa untuk belajar operasi pecahan secara bertahap berdasarkan tingkatan aktivitas belajar dalam PMR menurut Gravemeijer. Jika digambarkan dalam bentuk iceberg, trayektori pembelajaran untuk operasi penjumlahan dan pengurangan pecahan adalah sebagai berikut (Gambar 7).

Penelitian ini menunjukkan siswa dapat lebih berkembang dalam belajar tentang operasi penjumlahan dan pengurangan pecahan dengan menggunakan level aktivitas yang berbeda. Level yang dimaksudkan adalah level aktivitas berdasarkan pendekatan PMR menurut teori Gravemeijer yaitu, situasional, referensial, general dan formal. Pada penelitian ini gagasan dan konsep dari teori Gravemeijer digunakan dalam desain setiap tahap aktivitasnya. Konteks yang digunakan yaitu membagi makanan ringan serta aktivitas menaikan dan menurunkan penumpang. Temuan penelitian menunjukkan bahwa kedua konteks ini baik untuk membimbing siswa dalam proses matematisasi setelah mengikuti keempat level aktivitas menurut Gravemeijer.

Pada level pertama yaitu level situasional, siswa melakukan drama matematika dengan menggunakan serenteng makanan ringan dan susunan kursi-kursi Bemo berdasarkan skenario yang diberikan. Pada level ini pengetahuan prasyarat siswa sangat diperlukan yaitu pengetahuan tentang pengertian pecahan sebagai hubungan antara bagian-bagian dan sesuatu yang utuh (fraction as part of a wholel partwhole relation) serta kemampuan mempartisi sekumpulan objek diskrit. Berawal dari mengalami situasi (masalah kontekstual) dalam aktivitas drama matematika), siswa dapat memodelkannya sendiri dengan menyusun, melambangkan dan memvisualisasikan drama tersebut. Hal ini sesuai dengan prinsip pertama dari PMR yaitu penggunaan masalah kontekstual (use of contextual problems) dimana aktivitas membagi makanan ringan serta drama menaikkan dan menurunkan penumpang merupakan sumber untuk memproduksi sendiri prosedur operasi penjumlahan dan pengurangan pecahan. 
Pada level aktivitas kedua, siswa, menggunakan manik-manik (hitam dan putih), kartu pecahan kosong, dan senar. Pada tahap ini siswa memodelkan situasi dalam seuntai manikmanik yang digantungkan kartu pecahan. Selanjutnya siswa menggambarkanya sesuai untaian manik-manik yang dihasilkan. Hal ini sesuai dengan prinsip kedua dari PMR yaitu, penggunaan model-model (use of models) dimana untaian manik-manik dapat menjadi jembatan menuju pada operasi penjumlahan dan pengurangan menggunakan garis bilangan.

Pada level ketiga (aktivitas general), garis bilangan merupakan model yang sangat berguna untuk membimbing siswa menuju prosedur formal operasi penjumlahan dan pengurangan pecahan. Gambar untaian manik-manik yang digantungkan garis bilangan dijadikan awal untuk gagasan menggunakan garis bilangan dalam melakukan operasi penjumlahan dan pengurangan pecahan.

Pada level aktivitas keempat (level formal), siswa tidak lagi menggunakan garis bilangan. Dengan dibimbing oleh untaian bilangan, siswa membuat soal cerita sendiri yang ber-

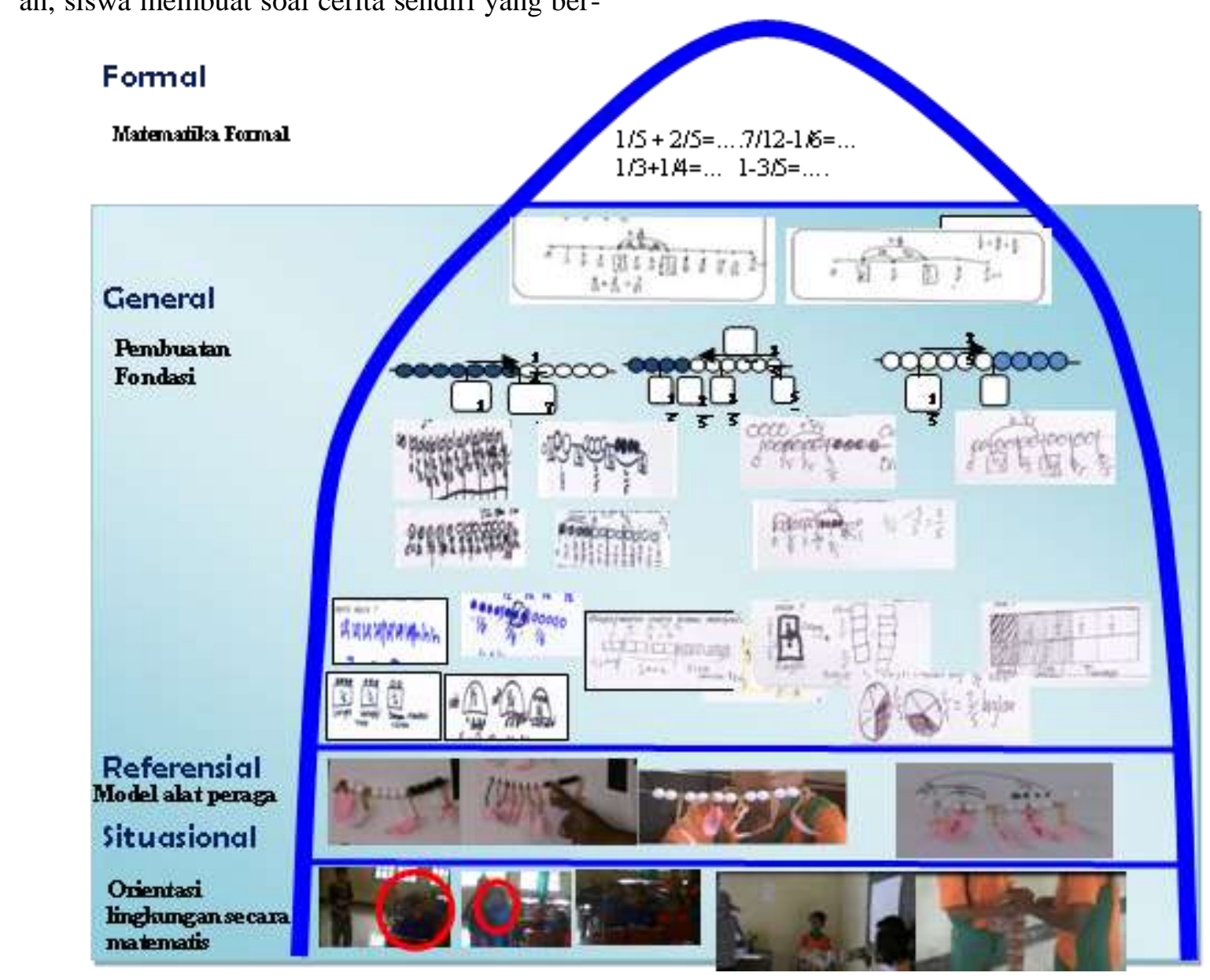

Gambar 7.Iceberg Operasi Penjumlahan dan Pengurangan Pecahan hubungan dengan penjumlahan dan pengurangan pecahan. Setelah membuat soal cerita mereka sendiri, siswa menyelesaikannya dengan kalimat matematika formal. Berdasarkan prinsip ketiga dari PMR yaitu, penggunaan kreativitas dan kontribusi siswa, representasi dari untaian manik-manik sebagai model dari situasi (drama matematika) ditransformasikan pada garis bilangan sebagai model untuk penalaran matematika yang lebih formal. Transformasi ini merupakan momen belajar yang penting bagi siswa dimana mereka dapat menggunakan model untuk beranjak dari konteks yang konkrit menuju matematika yang lebih formal.

Pada penelitian ini, ditemukan situasi yang menggambarkan proses dimana siswa saling membagi pengalaman dan gagasan dalam aktivitas pembelajaran (konggres matematika). Hal ini berhubungan dengan prinsip keempat dari PMR yaitu interaktivitas (interactivity) dimana siswa dapat membagi apa yang dipikirkan mereka dalam diskusi kelas. Dalam kesempatan tersebut guru memegang peranan penting untuk mengatur jalannya proses diskusi. 


\section{Kesimpulan}

Berdasarkan temuan-temuan dalam penelitian ini dapat disimpulkan bahwa siswa dapat lebih berkembang dalam belajar operasi pecahan dengan menggunakan tingkat aktivitas yang berbeda berdasarkan pendekatan PMR menurut teori Gravemeijer. Pada level pertama yaitu level situasional, Drama Matematika dapat menstimulasi pengetahuan informal siswa tentang prosedur operasi penjumlahan dan pengurangan pecahan. Pada level referensial, untaian manik-manik dan kartu pecahan menjadi model dari situasi drama matematika yang merupakan jembatan menuju gagasan penggunaan garis bilangan untuk operasi penjumlahan dan pengurangan pecahan. Pada level ketiga yaitu level general, siswa dapat menggunakan garis bilangan sebagai model untuk operasi penjumlahan dan pengurangan pecahan. Pada level formal, dengan bantuan untaian bilangan membawa siswa mengkonstruksi soal cerita sendiri dan menyelesaikan soal cerita yang dihasilkan dengan prosedur formal operasi penjumlahan dan pengurangan pecahan.

Berdasarkan hasil penelitian ini, dapat dilihat bahwa apa yang dihasilkan dalam penelitian ini hanya dalam skala yang relatif kecil, sehingga tidak semua temuan penelitian ini dapat digeneralisasi tetapi akan berimplikasi pada praktik pendidikan, khususnya sebagai sebuah inisiatif yang penting untuk memperbaiki pembelajaran matematika di Indonesia, terutama di Kabupaten Ngada, NTT. PMR dapat digunakan sebagai pendekatan dalam mengajar matematika, atau lebih spesifik seperti dalam penelitian ini untuk pembelajaran operasi penjumlahan dan pengurangan pecahan di kelas IV Sekolah Dasar. Siswa tidak dikondisikan untuk secara langsung belajar matematika formal tetapi dibiasakan untuk menemukan sendiri konsep matematika sejak awal ketika menyelesaikan permasalahan yang mereka alami secara informal.

\section{Daftar Pustaka}

Boulet, G. (1998). Didactical implications of children's difficulties in learning the fraction concept. Focus on Learning
Problems in Mathematics, 20 (4), 1934.

Gravemeijer. (2004). Local instruction theories as means of support for teacher in reform mathematics education. utrecht: Freudenthal Institute \& Department of Educational Research, Utrecht University.

Liu. C., Xin, Z., \& Li, X.,. (2012). The development of chinese students' understanding of the concept of fractions from fifth to eighth grade. Journal of Mathematics Education Vol.5, No. 1 August 2012, pp. 45-62

Mullis, et al. (1997). Mathematics achievement in the primary school years: IEA's third mathematics and science study. Boston: Center for the Study of Testing, Evaluation, and Educational Policy, Boston College.

Nalole, M. (2008). Pembelajaran pengurangan pecahan melalui pendekatan realistik di kelas V sekolah dasar. Inovasi, Vol 5, No.3, September 2008.

Permatasari, Elisabeth Ayunika. (2012). Early fraction learning of $3^{\text {rd }}$ grade students in sd laboratorium Unesa

Van Niekrek, T., (1999). Successes and obstacles in the development of grade 6 learners' conceptions of fractions. Paper presented at the 5th Annual Congress of the Association for Mathematics Education of South Africa (AMESA), Port Elizabeth, 5-9 July 1999.

Wheldon, D.A. (2008). Developing mathematical practices in a social context: an instructional sequence to support prospective elementary teachers' learning of fractions. Disertasi: University of Central Florida. Tidak diterbitkan.

Zulkardi. (2002). Developing a learning environment on realistic mathematics education for indonesian student teachers. Enschede: University of Twente. 